\title{
A joint probabilistic index for objective drought identification: the case study of Haiti
}

\author{
Beatrice Monteleone $^{1}$, Brunella Bonaccorso ${ }^{2}$, and Mario Martina ${ }^{1}$ \\ ${ }^{1}$ Scuola Universitaria Superiore IUSS Pavia, Pavia, 27100, Italy \\ ${ }^{2}$ Department of Engineering, University of Messina, St Agata, Messina, 98166, Italy
}

Correspondence: Beatrice Monteleone (beatrice.monteleone@iusspavia.it)

Received: 6 September 2019 - Discussion started: 10 September 2019

Revised: - - Accepted: 17 January 2020 - Published: 19 February 2020

\begin{abstract}
Since drought is a multifaceted phenomenon, more than one variable should be considered for a proper understanding of such an extreme event in order to implement adequate risk mitigation strategies such as weather or agricultural indices insurance programmes or disaster risk financing tools. This paper proposes a new composite drought index that accounts for both meteorological and agricultural drought conditions by combining in a probabilistic framework two consolidated drought indices: the standardized precipitation index (SPI) and the vegetation health index (VHI). The new index, called the probabilistic precipitation vegetation index (PPVI), is scalable, transferable all over the globe and can be updated in near real time. Furthermore, it is a remote-sensing product, since precipitation is retrieved from satellite data and the VHI is a remote-sensing index. In addition, a set of rules to objectively identify drought events is developed and implemented. Both the index and the set of rules have been applied to Haiti. The performance of the PPVI has been evaluated by means of a receiver operating characteristic curve and compared to that of the SPI and VHI considered separately. The new index outperformed SPI and VHI both in drought identification and characterization, thus revealing potential for an effective implementation within drought early-warning systems.
\end{abstract}

\section{Introduction}

Every year droughts affect an increasing number of people. In the years from 2014 to 2018, more than 70 drought events were reported all over the world and about 450 million people suffered because of drought-related impacts (CRED,
2017). Due to its complexity, various definitions of the phenomenon have been proposed by different institutions, such as the World Meteorological Organization (WMO), the Food and Agriculture Organization (FAO), and the United Nations Convention to Combat Desertification (UNCCD). All the institutions focus their attention on a specific aspect of drought: the WMO on the lack of precipitation, the FAO on the decline in crop productivity and the UNCCD on the loss of arable land.

In addition, the quantification of drought effects is a complicated task, since drought impacts are non-structural, widespread over large areas, and of different types and magnitudes within the drought-affected area; they also depend on economic, social and environmental system vulnerabilities (Wilhite, 2000).

Drought identification through an objective and automatic determination of drought onset, termination and severity allows for the timely adoption of appropriate risk management strategies, such as weather index insurance programmes (Barnett and Mahul, 2007), agricultural index insurance programmes (Jensen and Barrett, 2017), disaster financing (Guimarães Nobre et al., 2019; Linnerooth-Bayer and Hochrainer-Stigler, 2015) and early action planning (Drechsler and Soe, 2016).

Drought features are usually determined through the use of two instruments: indicators, which are variables and parameters used to assess drought conditions (such as precipitation, temperature and others), and indices, which are numerically computed values from meteorological or hydrological inputs (World Meteorological Organization and Global Water Partnership, 2016). More than 100 indices have been developed by the scientific community (Zargar et al., 2011), 
each one focusing on a specific aspect of drought (meteorological, hydrological, agricultural and so on). Meteorological drought is related to precipitation shortages; hydrological drought refers to periods of precipitation shortfall affecting surface water supply (Sheffield and Wood, 2011), while agricultural drought is conventionally linked to soil moisture deficit. Insufficient soil moisture leads to crop failure and consequent yield reduction; therefore the first economic sector that suffers because of drought is agriculture, particularly in those areas where it relies on rainfall. A deeper understanding of agricultural drought dynamics can promote the adoption of risk reduction strategies, such as crop insurance programmes.

In recent years various remote-sensing indices have been developed and can be employed in agricultural drought monitoring. The most widespread is the normalized difference vegetation index (NDVI), which uses NOAA AVHRR satellite data to monitor vegetation greenness (Kogan, 1995a). The main advantages of the NDVI are the very high spatial resolution and the global coverage. The NDVI has already been applied in drought monitoring, such as in Gu et al. (2008). Many products were derived from the NDVI, such as the vegetation condition index (VCI), which compares the current NDVI to the range of values observed in the same period in previous years (Liu and Kogan, 1996; Kogan, 1995b), and the standardized vegetation index (SVI), which describes the probability of vegetation condition deviation from normal (Peters et al., 2002). A suite of agricultural drought indices is presented in Table 1.

Since drought is a complex phenomenon, a single index or indicator can be insufficient to fully characterize drought severity and extent. The combination of more than one indicator can be invaluable in the evaluation of all the variables involved in drought monitoring, such as precipitation, soil moisture and streamflow. Over the past 20 years many composite indicators, relying on two or more drought indices or indicators, have been proposed to overcome the issues related to the use of a single variable. Table 2 shows a list of selected composite indices that can be used in agricultural drought monitoring since, in their formulation, soil moisture, vegetation condition or variables related to water availability for plants are included.

Multiple methods for taking into account the multivariate behaviour of drought have been explored (Hao and Singh, 2015, 2016). The vegetation drought response index (VegDRI), for example, uses a data mining approach to combine multiple inputs such as the SPI, the NDVI and the Palmer drought severity index (PDSI). A weighted linear combination of the inputs is quite common; it is applied to construct the composite drought indicator (CDI) for Morocco, the vegetation health index (VHI) and the objective blend of drought indicators (OBDI). The United States Drought Monitor (USDM) also applies a weighted linear combination of the inputs but adds an expert judgement to define the drought class.
In the last few years multiple studies have focused the attention on modelling the joint behaviour of two drought characteristics or indices applying bivariate or multivariate statistical approaches. In various cases bivariate distributions are developed by means of copulas as in Serinaldi et al. (2009) and Bonaccorso et al. (2012), where the joint behaviour of various drought properties is investigated, or in Shiau (2006), where two-dimensional copulas are employed to study the joint behaviour of drought duration and severity in Taiwan. Shiau et al. (2007) also investigate the hydrological droughts of the Yellow River in China using a bivariate distribution to model drought duration and severity jointly. A trivariate Plackett copula is used in Songbai and Singh (2010) to model drought duration, severity and inter-arrival time jointly.

The use of copulas to quantify the joint behaviour of drought indices is gaining popularity too. Many drought indices derived by multivariate distributions have been proposed. For example the multivariate standardized drought index (MSDI; Hao and Aghakouchak, 2013), which combines the SPI and the standardized soil moisture index (SSI), uses copulas to form joint probabilities of precipitation and soil moisture content, while the joint drought index (JDI; Kao and Govindaraju, 2010) does the same for obtaining the joint probabilities while considering precipitation and streamflow. The composite agrometeorological drought index accounting for seasonality and autocorrelation (AMDI-SA) combines two drought indices, the modified SPI and the modified SSI, employing both the copula concept and the Kendall function (Bateni et al., 2018). The use of copulas seems promising and is highly effective when dealing with two or more variables. An advantage of copula functions is the fact that the index derived from this approach has a probabilistic form.

Both single and composite indices for agricultural drought monitoring showed some limitations, highlighted in Tables 1 and 2. Single indices often rely on multiple inputs, are available only for some locations or identify all types of vegetation stresses. In any case single indices do not account for the multivariate nature of drought. Composite indices often rely on relatively new datasets; in many cases a short period of record is available (for example the VegDRI records start in 2009) or the index is not available in near real time; some of them are specifically designed for a well-identified region (the OBDI and the USDM are available only for the USA, the Combined Drought Indicator only for Europe); other indices do not consider the meteorological aspect of drought (temperature vegetation index, TVX, and vegetation temperature condition index, VTCI, are based on the NDVI and the land surface temperature); other ones do not have a sufficiently refined spatial resolution (MSDI). Most of them, with the exception of the AMDI-SA and MSDI, are not expressed in probabilistic terms; therefore uncertainty quantification and evaluation is not an easy task.

In this paper, we propose the following: 
Table 1. An overview of indices used in agricultural drought monitoring; Met is meteorological, Hydro is hydrological, Ag is agricultural.

\begin{tabular}{|c|c|c|c|c|c|}
\hline Index & Inputs & Drought type & Pros & Cons & Reference \\
\hline ETDI & Modelled (SWAT) & $\mathrm{Ag}$ & $\begin{array}{l}\text { Analysis of both actual and po- } \\
\text { tential evapotranspiration }\end{array}$ & Complex calculations & Narasimhan and Srinivasan (2005) \\
\hline NDVI & Near infrared & $\mathrm{Ag}$ & $\begin{array}{l}\text { High resolution, global cover- } \\
\text { age, remote sensing }\end{array}$ & Need for data processing & Kogan (1995a) \\
\hline SMAI & $\begin{array}{l}\text { Precipitation, temper- } \\
\text { ature, available water } \\
\text { content }\end{array}$ & $\mathrm{Ag}$ & Water balance approach & Data requirements & Bergman et al. (1988) \\
\hline SMDI & Modelled (SWAT) & $\mathrm{Ag}$ & $\begin{array}{l}\text { Adaptable to different crop } \\
\text { types }\end{array}$ & Based upon output from SWAT & Narasimhan and Srinivasan (2005) \\
\hline SSI & Soil moisture & $\mathrm{Ag}$ & $\begin{array}{l}\text { Uses soil moisture only, stan- } \\
\text { dardized }\end{array}$ & Based on one variable & Hao and Aghakouchak (2013) \\
\hline SVI & VCI & $\mathrm{Ag}$ & Standardized, remote sensing & Scarcely employed & Peters et al. (2002) \\
\hline SWS & $\begin{array}{l}\text { Available water con- } \\
\text { tent, rooting depth, soil } \\
\text { water deficit, soil type }\end{array}$ & $\mathrm{Ag}$ & Well-known calculations & $\begin{array}{l}\text { Poor performance on non- } \\
\text { homogeneous soils }\end{array}$ & BC Ministry for Agriculture (2015) \\
\hline TCI & Brightness temperature & $\mathrm{Ag}$ & $\begin{array}{l}\text { High resolution, global cover- } \\
\text { age, remote sensing }\end{array}$ & $\begin{array}{l}\text { Only brightness temperature is } \\
\text { considered }\end{array}$ & Kogan (1995a) \\
\hline VCI & NDVI & $\mathrm{Ag}$ & $\begin{array}{l}\text { High resolution, global cover- } \\
\text { age, remote sensing }\end{array}$ & $\begin{array}{l}\text { Identifies all vegetation } \\
\text { stresses, not only the ones due } \\
\text { to drought }\end{array}$ & Liu and Kogan (1996) \\
\hline CMI & $\begin{array}{l}\text { Precipitation, tempera- } \\
\text { ture }\end{array}$ & $\mathrm{Ag}$ & Weekly temporal resolution & $\begin{array}{l}\text { Specifically developed for } \\
\text { grain-producing regions in the } \\
\text { USA }\end{array}$ & Palmer (1968) \\
\hline CSDI & $\begin{array}{l}\text { Precipitation, tempera- } \\
\text { ture, wind speed, so- } \\
\text { lar radiation, dew point } \\
\text { temperature, soil pro- } \\
\text { file, plant phenology }\end{array}$ & $\mathrm{Ag}$ & $\begin{array}{l}\text { Very specific for each crop, } \\
\text { based on plant development }\end{array}$ & $\begin{array}{l}\text { Many inputs with a daily tem- } \\
\text { poral resolution }\end{array}$ & Meyer et al. (1993) \\
\hline CWSI & $\begin{array}{l}\text { Actual and potential } \\
\text { evapotranspiration }\end{array}$ & $\mathrm{Ag}$ & $\begin{array}{l}\text { Useful for irrigation schedul- } \\
\text { ing, remote sensing }\end{array}$ & $\begin{array}{l}\text { To be computed from MODIS } \\
\text { data }\end{array}$ & Idso et al. (1981) \\
\hline NMDI & NDVI & $\mathrm{Ag}$ & $\begin{array}{l}\text { Uses vegetation condition and } \\
\text { soil water content }\end{array}$ & $\begin{array}{l}\text { Poor performance in areas with } \\
\text { sparse vegetation }\end{array}$ & Wang and Qu (2007) \\
\hline RSM & $\begin{array}{l}\text { Precipitation, temper- } \\
\text { ature, evapotranspira- } \\
\text { tion, soil properties, } \\
\text { crop features, crop } \\
\text { management practice }\end{array}$ & $\mathrm{Ag}$ & $\begin{array}{l}\text { Computes the water balance } \\
\text { with various methods }\end{array}$ & Need for multiple inputs & Thornthwaite and Mather (1955) \\
\hline DTx & $\begin{array}{l}\text { Modelled (water bal- } \\
\text { ance) }\end{array}$ & $\mathrm{Ag}$ & $\begin{array}{l}\text { Computes an integrated transpi- } \\
\text { ration deficit over a period of } \\
\text { time }\end{array}$ & Need for multiple inputs & Matera et al. (2007) \\
\hline ADI & $\begin{array}{l}\text { Precipitation, snow wa- } \\
\text { ter content, streamflow, } \\
\text { reservoir storage, evap- } \\
\text { otranspiration, soil wa- } \\
\text { ter content }\end{array}$ & Met Hydro Ag & Water balance approach & Need for multiple inputs & Keyantash and Dracup (2004) \\
\hline
\end{tabular}

1. a new drought index, the probabilistic precipitation vegetation index (PPVI), that takes advantage of wellconsolidated indices, the standardized precipitation index (SPI; Mckee et al., 1993) and the vegetation health index (VHI; Kogan, 1997), and tries to overcome their individual limitations by coupling them in a probabilistic framework through the use of a bivariate normal distribution function;

2. a framework to identify a drought event using the new index, i.e. a set of rules for the definition of a drought event; when the set of conditions is verified, a drought event is identified based on the new index; otherwise, no drought event is identified.
With respect to the indices already available in the literature, we will show in this paper that the new index has some interesting features:

- It is able to identify drought-driven events of vegetation stress.

- It is parsimonious in terms of number of inputs required.

- It is a remote-sensing product with high spatial and temporal resolution.

- It is based on quasi-near-real-time datasets, with a relatively short latency time (less than 1 week).

- More than 30 years of records are available at global scale for its calibration. 
Table 2. An overview of aggregate and composite drought indices useful for agricultural drought monitoring; Met is meteorological, Hydro is hydrological, $\mathrm{Ag}$ is agricultural. Input abbreviations not defined in the text are as follows: fraction of absorbed photosynthetically active radiation (fAPAR), soil moisture anomaly (SMA), evapotranspiration (ET) and land surface temperature (LST).

\begin{tabular}{|c|c|c|c|c|c|}
\hline Index & Inputs & Drought type & Pros & Cons & Reference \\
\hline VegDRI & SPI, NDVI, PDSI & $\mathrm{Ag}$ & $\begin{array}{l}\text { Use of surface and remote- } \\
\text { sensing data }\end{array}$ & $\begin{array}{l}\text { Short period of record, } \\
\text { available only for the con- } \\
\text { tiguous USA }\end{array}$ & Brown et al. (2008) \\
\hline VHI & VCI, TCI & $\mathrm{Ag}$ & $\begin{array}{l}\text { High temporal resolution, } \\
\text { global coverage at a high } \\
\text { spatial resolution, } 30+ \\
\text { years of records }\end{array}$ & $\begin{array}{l}\text { Identifies all types of veg- } \\
\text { etation stress, not only the } \\
\text { drought-related ones }\end{array}$ & Kogan (1990) \\
\hline MSDI & SPI, SSI & Met Ag & $\begin{array}{l}\text { Global coverage, remote } \\
\text { sensing }\end{array}$ & $\begin{array}{l}\text { Grid size may not repre- } \\
\text { sent all areas and climate } \\
\text { regimes equally well, short } \\
\text { period of record }\end{array}$ & Hao and Aghakouchak (2013) \\
\hline $\begin{array}{l}\text { Combined } \\
\text { Drought } \\
\text { Indicator }\end{array}$ & SPI3, fAPAR, SMA & Met Ag & $\begin{array}{l}10 \mathrm{~d} \text { temporal resolution, } \\
\text { high spatial resolution } \\
(5 \mathrm{~km})\end{array}$ & $\begin{array}{l}\text { Short period of record } \\
\text { (2012), available only in } \\
\text { Europe, hard to replicate }\end{array}$ & Sepulcre-Canto et al. (2012) \\
\hline $\begin{array}{l}\text { Morocco } \\
\text { CDI }\end{array}$ & SPI, ET, LST, NDVI & Met Ag & $\begin{array}{l}\text { High spatial resolution } \\
(5 \mathrm{~km})\end{array}$ & $\begin{array}{l}\text { Monthly temporal resolu- } \\
\text { tion, available for Morocco } \\
\text { only, short period of record }\end{array}$ & Bijaber et al. (2018) \\
\hline Hybrid DI & SPI, SWSI, PDSI & Met Hydro Ag & $\begin{array}{l}\text { Function of damage, in- } \\
\text { cludes all types of droughts }\end{array}$ & $\begin{array}{l}\text { Need for detailed informa- } \\
\text { tion on economic damage }\end{array}$ & Karamouz et al. (2009) \\
\hline VegOut & $\begin{array}{l}\text { SPI, NDVI, oceanic in- } \\
\text { dices }\end{array}$ & Met Ag & $\begin{array}{l}\text { Combination of climate in- } \\
\text { formation, vegetation con- } \\
\text { dition, oceanic indices and } \\
\text { land cover }\end{array}$ & $\begin{array}{l}\text { Need for a high number of } \\
\text { parameters }\end{array}$ & Tadesse and Wardlow (2007) \\
\hline OBDI & $\begin{array}{l}\text { Precipitation, MPDI, } \\
\text { soil moisture }\end{array}$ & Met Ag & $\begin{array}{l}\text { First attempt to combine } \\
\text { and weight various inputs }\end{array}$ & $\begin{array}{l}\text { Specifically designed for } \\
\text { the USA }\end{array}$ & Dieker et al. (2010) \\
\hline USDM & $\begin{array}{l}\text { PDSI, soil moisture, } \\
\text { streamflow, percent of } \\
\text { normal precipitation, } \\
\text { SPI, OBDI }\end{array}$ & Met Hydro Ag & $\begin{array}{l}\text { Combines many inputs and } \\
\text { expert knowledge, weekly } \\
\text { temporal resolution }\end{array}$ & Available only for the USA & Svoboda et al. (2002) \\
\hline TVX & NDVI, LST & $\mathrm{Ag}$ & $\begin{array}{l}\text { Combination of NDVI and } \\
\text { temperature effects, remote } \\
\text { sensing }\end{array}$ & $\begin{array}{l}\text { To be computed from } \\
\text { NDVI and LST datasets }\end{array}$ & Lambin and Ehrlich (1995) \\
\hline VTCI & NDVI, LST & $\mathrm{Ag}$ & $\begin{array}{l}\text { Combination of NDVI and } \\
\text { temperature effects, remote } \\
\text { sensing }\end{array}$ & $\begin{array}{l}\text { To be computed from } \\
\text { NDVI and LST datasets }\end{array}$ & Wang et al. (2001) \\
\hline AMDI-SA & $\begin{array}{l}\text { Modified SPI, modified } \\
\text { SSI }\end{array}$ & Met Ag & $\begin{array}{l}\text { Combination of SPI and } \\
\text { SSI, standardized }\end{array}$ & Complex calculations & Bateni et al. (2018) \\
\hline
\end{tabular}

The paper is structured as follows: Sect. 2 describes the datasets employed in the development of the new index and presents the methodology used to combine the SPI and the VHI; Sect. 3 illustrates the application to the case study, shows the validation process of the new index, and compares the performance of the new index to those of the SPI and the VHI considered separately; in addition the advantages related to the adoption of the index and the possible applications in agricultural drought risk management are summarized.

\section{Datasets and methods}

\subsection{Datasets}

Two remote-sensing datasets were used: one for precipitation and the other for the VHI. Precipitation was retrieved from the satellite-only Climate Hazards Group Infrared Precipitation (CHIRP) dataset. CHIRP has a quasi-global coverage $\left(50^{\circ} \mathrm{S}-50^{\circ} \mathrm{N}\right)$; high spatial resolution $\left(0.05^{\circ}\right)$; and daily, pentadal and monthly temporal resolution. Records start from 1 January 1981. CHIRP was chosen because it has been specifically developed to monitor agricultural drought. The use of CHIRP instead of CHIRPS (the Climate Hazards Group Infrared Precipitation with Stations) is related to the data latency time. Since the aim of the work is the development of an index for near-real-time drought monitoring, the product with the shortest latency time was selected. CHIRPS data have a latency time of about 3 weeks (Funk et al., 2015), while CHIRP's latency is about $2 \mathrm{~d}$, as can be checked on the dataset's website (Climate Hazard Group, 2015). The development and the main characteristics of the dataset are described in Funk et al. (2015). In the present study CHIRP with a daily temporal resolution was used to have the possi- 
bility of computing weekly precipitation. Data are available on the project website (Climate Hazard Group, 1999).

The vegetation health index was retrieved from the global vegetation health products (global VHP) of the National Oceanic and Atmospheric Administration (NOAA) Center for Satellite Applications and Research (Kogan, 1997). Data can be retrieved from the NOAA website (NOAA, 2011). The dataset contains blended VHP derived from VIIRS (2013-present) and AVHRR (1981-2012) GAC data. The dataset has $4 \mathrm{~km}$ spatial resolution, weekly temporal resolution and global coverage. Both the selected datasets are freely available.

\subsection{Methods}

\subsubsection{The standardized precipitation index}

As previously mentioned, two consolidate drought indices were combined: the SPI and the VHI. The SPI was selected because it is a commonly used index to detect meteorological drought; it is standardized, and therefore SPI values can be compared even in different climate regimes; and it is recommended by the WMO (World Meteorological Organization, 2009).

SPI computation is based on a long-term precipitation record for a desired period. The precipitation record is then fitted to a probability distribution (in this work a gamma distribution was used), which is then transformed into a normal distribution. Traditionally monthly precipitation records are employed, and the SPI is computed aggregating precipitation at a predefined time step (for example 1, 3, 6, 9 and 12 months are the aggregation periods suggested by the WMO; World Meteorological Organization, 2009).

In the present work, weekly precipitation records were used. The SPI aggregation period was then selected, and the index, computed over one of the traditional aggregation periods, was updated every week. The SPI is normally distributed by definition. Conventionally drought starts when the SPI is lower than -1 and ends when the SPI comes back to the value of 0 (Mckee et al., 1993). Drought classification according to the SPI, as proposed in Mckee et al. (1993), is reported in Table 3 . The percentages reported in the third column of Table 3 indicate the probability of SPI values falling within the range reported in the second column of the same table.

\subsubsection{The vegetation health index}

The VHI is a remote-sensing index developed to include the effects of temperature on vegetation; in fact, it combines the VCI with the temperature condition index (TCI; Kogan, 1995a), which is another remote-sensing index used to determine vegetation stress caused by temperature and excessive wetness. The VHI is based on a linear combination of VCI and TCI: $\mathrm{VHI}=\alpha \mathrm{VCI}+(1-\alpha) \mathrm{TCI}$. As suggested by Kogan
Table 3. Drought classification based on SPI according to Mckee et al. (1993).

\begin{tabular}{llr}
\hline Category & SPI & Probability (\%) \\
\hline Extremely wet & 2.00 and above & 2.3 \\
Severely wet & 1.50 to 1.99 & 4.4 \\
Moderately wet & 1.00 to 1.49 & 9.2 \\
Near normal & -0.99 to 0.99 & 68.2 \\
Moderately dry & -1.49 to -1.00 & 9.2 \\
Severely dry & -1.50 to -1.99 & 4.4 \\
Extremely dry & -2 and below & 2.3 \\
\hline
\end{tabular}

Table 4. Drought classification based on VHI according to Dalezios et al. (2017).

\begin{tabular}{ll}
\hline Category & VHI \\
\hline Extremely dry & $\leq 10$ \\
Severely dry & $\leq 20$ \\
Moderately dry & $\leq 30$ \\
Mild dry & $\leq 40$ \\
Normal & $>40$ \\
\hline
\end{tabular}

et al. (2016), when VCI and TCI contributions are not known, $\alpha=0.5$. One drawback of the VHI is the impossibility of identifying the cause of the vegetation stress; in fact, vegetation can suffer because of various events: excessive wetness, pests, fires, droughts or other factors. The VCI is a biophysical indicator of a lack of precipitation but can also be seen as representing drought impacts on the ground (Bachmair et al., 2016). It goes from 0 , which stands for vegetation in very bad conditions, to 100 , meaning perfectly healthy vegetation. The classification scheme of the VHI, as proposed in Dalezios et al. (2017), is presented in Table 4.

The VHI is standardized to make comparisons with the SPI easier. As mentioned by Peters et al. (2002), all remotesensing indices can be expressed as deviations from the mean; therefore, the standardized variable, $\mathrm{VHI}_{\text {st }}$, is computed according to the following equation:

$\mathrm{VHI}_{\mathrm{st}}=\frac{\mathrm{VHI}-\overline{\mathrm{VHI}}}{\sigma}$,

where $\overline{\mathrm{VHI}}$ is the mean of the distribution and $\sigma$ its standard deviation. Thus, the same procedure proposed in Peters et al. (2002) in the case of the NDVI has been applied to the VHI. The standardized variable, $\mathrm{VHI}_{\mathrm{st}}$, has a distribution with 0 mean and 1 as standard deviation.

\subsubsection{The probabilistic precipitation vegetation index (PPVI)}

The probabilistic precipitation vegetation index (PPVI) is a composite index that takes into account both meteorological drought through the SPI and agricultural drought conditions by including the VHI. 
In order to combine the two consolidated indices, the following preparatory steps are performed:

1. extraction of the area under study from both the datasets;

2. regridding of both precipitation and the VHI to bring them to the same spatial resolution $\left(0.05^{\circ}\right)$;

3. aggregation of precipitation at a weekly timescale (CHIRP has daily temporal resolution);

4. computation and weekly update of the SPI according to the methodology proposed in USDA Risk Management Agency et al. (2006), where precipitation is fitted to a gamma distribution; the goodness of fit to the gamma distribution has been verified by means of probability plot;

5. standardization of the VHI, as previously described.

The combination of the SPI and VHI is performed using a bivariate normal distribution function, as defined by Kotz et al. (2000). The normality of the SPI and $\mathrm{VHI}_{\text {st }}$ distributions has been verified as will be shown in Sect. 3.2. Therefore it is acceptable to assume that the joint probability of the two considered distributions takes the form of the bivariate normal for correlated variables:

$$
\begin{aligned}
& f(s, v)=\frac{1}{2 \pi \sigma_{s} \sigma_{v} \sqrt{1-\rho^{2}}} \exp \left(-\frac{1}{2\left(1-\rho^{2}\right)}\right. \\
& \left.\cdot\left[\frac{\left(s-\mu_{s}\right)^{2}}{\sigma_{s}}+\frac{\left(v-\mu_{v}\right)^{2}}{\sigma_{v}}+\frac{2 \rho\left(s-\mu_{s}\right)\left(v-\mu_{v}\right)}{\sigma_{s} \sigma_{v}}\right]\right),
\end{aligned}
$$

where the following notation is adopted. The SPI is identified as $s$, and the $\mathrm{VHI}_{\mathrm{st}}$ is identified as $v$. The mean and the standard deviation of the SPI distribution $f(s)$ are respectively, by construction, $\mu_{s}=0$ and $\sigma_{s}=1$, and the mean and standard deviation of the $\mathrm{VHI}_{\text {st }}$ distribution $f(v)$ are respectively $\mu_{v}=0$ and $\sigma_{v}=1$. The covariance matrix $\boldsymbol{\Sigma}$ and the correlation coefficient $\rho$ are defined according to Eqs. (3) and (4) respectively, where $\sigma_{s v}$ is the covariance between $s$ and $v$.

$\boldsymbol{\Sigma}=\left[\begin{array}{cc}\sigma_{s}^{2} & \rho \sigma_{s} \sigma_{v} \\ \rho \sigma_{s} \sigma_{v} & \sigma_{v}^{2}\end{array}\right]$

$\rho=\frac{\sigma_{s v}}{\sigma_{s} \sigma_{v}}$

To check the assumption of normality for the joint distribution, the joint probability values, retrieved from Eq. (2), are plotted against the bivariate empirical cumulative distribution values (Fig. 1), as performed in Kao and Govindaraju (2010). The bivariate empirical copula for the random variables $s$ and $v$ has been evaluated according to Nelsen (2006) using the following equation:

$C\left(\frac{i}{m}, \frac{j}{m}\right)=\frac{\#\left(s \leq s_{(i)}, v \leq v_{(j)}\right)}{m}=\frac{m_{1}}{m}$,

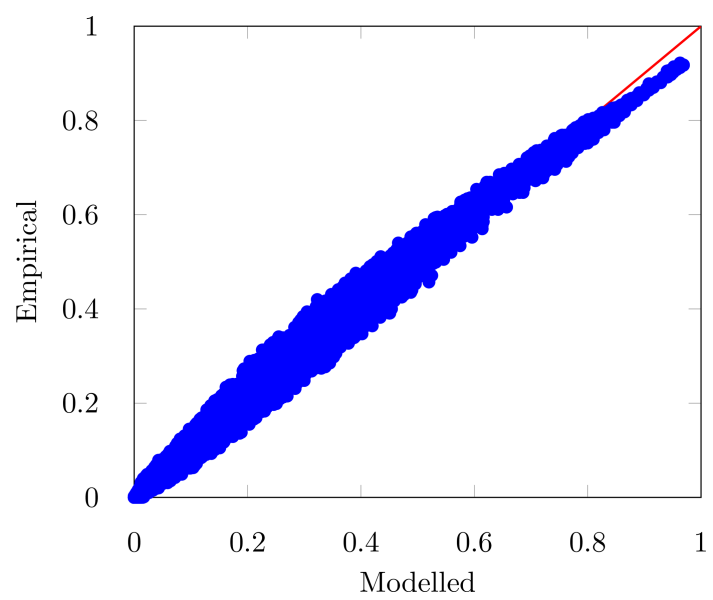

Figure 1. PPVI validation: empirical copula versus bivariate joint probability function. The red line corresponds to the $45^{\circ}$ line. Joint probability values have been computed from Eq. (2), while empirical copula values according to Eq. (5).

Table 5. Drought classification according to PPVI.

\begin{tabular}{llr}
\hline Category & PPVI & Probability $(\%)$ \\
\hline Extremely wet & 1.04 and above & 2.3 \\
Severely wet & 0.58 to 1.03 & 4.4 \\
Moderately wet & 0.13 to 0.57 & 9.2 \\
Near normal & -1.68 to 0.12 & 68.2 \\
Moderately dry & -2.14 to -1.69 & 9.2 \\
Severely dry & -2.15 to -2.59 & 4.4 \\
Extremely dry & -2.6 and below & 2.3 \\
\hline
\end{tabular}

where $s_{(i)}$ and $v_{(j)}(1 \leq i, j \leq m)$ are ordered statistics of the SPI sample of size $m$ and $m_{1}$ is the number of samples $\left(s_{(k)}, v_{(k)}\right)$ satisfying $\left(s_{(k)} \leq s_{(i)}\right.$ and $\left.v_{(k)} \leq v_{(j)}\right)$ with $1 \leq k \leq m$. The resulting plot is shown in Fig. 1 .

Since the data lie on the $45^{\circ}$ line, it is fair to assume that the joint probability $f(s, v)$ is normal. Therefore, a normalization of the index is performed through normal quantile transformation.

By keeping the same probability intervals of the SPI, we can compute the PPVI values for the drought classification as shown in Table 5.

\subsubsection{Identification of drought events}

Once the index is defined, the set of rules to establish when a grid cell is in a drought should be identified. In particular, two parameters have to be identified:

1. a threshold $Z$ of the index that marks the beginning of a drought in a grid cell

2. a threshold $z$ that marks the end of a drought in the same grid cell. 
According to the model proposed here, a drought in a grid cell starts when the index is lower than $Z$ and ends when the index is above $z$. Then regional drought events are defined. Again, two parameters are identified: $N$ and $n$. A drought events starts if more than $N$ grid cells are in drought conditions and ends if less than $n$ grid cells are in drought conditions.

\subsubsection{Skill assessment}

Observations of drought are compared with the model outputs for various combinations of thresholds $Z, z, N$ and $n$. The receiver operating characteristic (ROC) curve is used for this comparison. The ROC curve was at first used in signal detection; its use in meteorological applications is documented and well described in Joliffe and Stephenson (2012). The ROC curve is employed to classify instances, as in the present case. The ROC curve was already employed in various studies to compare the performance of a model versus observations with varying thresholds (Zhu et al., 2016; Khadr, 2016). The contingency matrix (shown in Table 6) is a 2-by-2 matrix to visualize the disposition of a set of instances. True positives or hits are represented by the weeks that are reported to be in drought conditions in the observations and are correctly identified as drought weeks by the model. True negatives (correct rejections) are represented by those weeks that are not in drought according to both the observations and the model. Those weeks that are recorded as drought according to the observations but are not identified as drought weeks by the model are considered as false negatives (missing events), while false positives (false alarms) are represented by the weeks that are not in drought conditions according to the observations but are identified as drought weeks by the model. In this paper for each combination of thresholds $Z, z, N$ and $n$, probability of detection (POD), or hit rate, and probability of false detection (POFD), or false alarm rate, are computed according to Joliffe and Stephenson (2012) with the following equations:

$$
\begin{aligned}
& \mathrm{POD}=\frac{\mathrm{TP}}{\mathrm{TP}+\mathrm{FN}}, \\
& \mathrm{POFD}=\frac{\mathrm{TN}}{\mathrm{TN}+\mathrm{FP}},
\end{aligned}
$$

where TP, TN, FP and FN are defined as in Table 6.

The optimal threshold for a ROC curve is the one for which the distance from the $45^{\circ}$ line is maximal (Zhu et al., 2016). The performances of the model based on the PPVI in identifying drought events have been evaluated on the case study described in the next section.

\subsubsection{Case study}

The case study region is Haiti. The country, which has an extent of $27750 \mathrm{~km}^{2}$, is located in the Caribbean's Greater Antilles and shares the island of Hispaniola with the Dominican

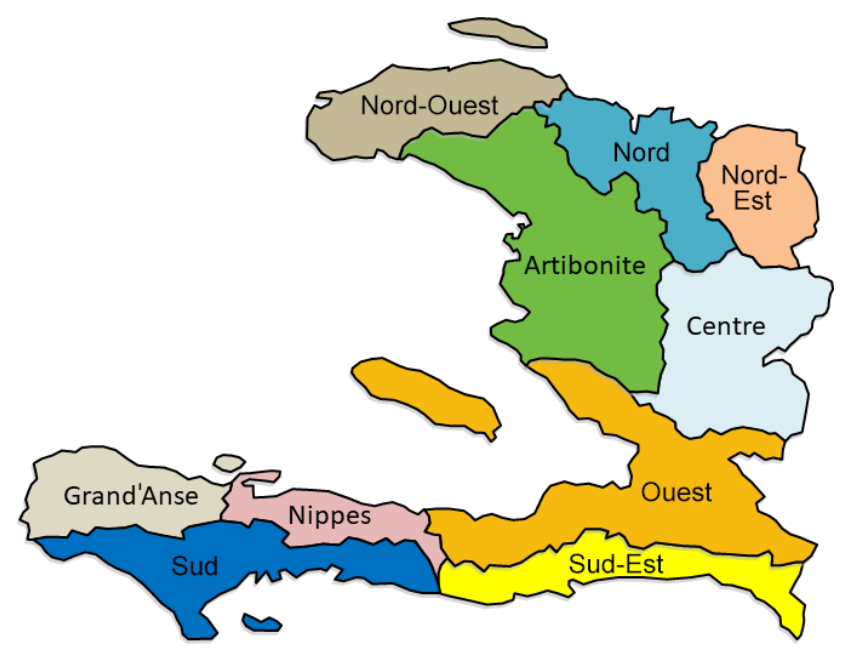

Figure 2. Map of Haiti departments.

Republic. The climate is predominantly tropical, with daily temperatures ranging between 19 and $28^{\circ} \mathrm{C}$ during winter and between 23 and $33^{\circ} \mathrm{C}$ during summer. The island topography is varied; the central region is mainly mountainous, while the northern and western regions are near the coastline. Annual precipitation in the central region averages $1200 \mathrm{~mm}$, while in the lowlands it is about $550 \mathrm{~mm}$ (GFDRR, 2011). Haiti is subject to the variability associated with El Niño and La Niña phenomena, with El Niño bringing drier and hotter conditions and La Niña a colder and wetter climate. Haiti experiences a first rainy season from April to July and a second, and most important, rainy season from August to the end of November. The dry season starts in December and goes on until the end of March (FEWSNET, 2019).

Haiti is divided administratively into 10 departments (Fig. 2), with people living mainly in Ouest, where the capital Port-au-Prince is located, and in Artibonite. The total population in 2017 was about 11 million people (World Bank, 2017). Haiti is the poorest country in the Western Hemisphere; the economy is mainly agricultural. Of the country's total area, $67 \%$ is devoted to agriculture, but only $4.35 \%$ of the agricultural area is irrigated (Trading Economics, 2013), posing a major threat to local production.

Haiti produces over half of the world's vetiver oil (used in cosmetics), and mangos and cocoa are the most important export crops. Two-fifths of all Haitians depend on the agriculture sector, mainly small-scale subsistence farming. The country is prone to all types of natural hazards. Earthquakes, storms, hurricanes, landslides and droughts have caused huge damage and losses in recent years. Haiti was ranked as the third country most affected by extreme weather events in terms of lives lost and economic damage in the period from 1994 to 2013 (GFDRR, 2011). More than $96 \%$ of the population lives in areas at risk of two or more hazards. The most frequent disasters are floods and storms, but droughts are the disasters involving the highest number of persons (Fig. 3). 
Table 6. Contingency table for the deterministic estimates of a series of binary events (Joliffe and Stephenson, 2012).

\begin{tabular}{llll}
\hline \multirow{2}{*}{$\begin{array}{l}\text { Events } \\
\text { estimated }\end{array}$} & Yes & No & Total \\
\hline Yes & TP (true positives or hits) & FP (false positives or false alarms) & TP + FP \\
No & FN (false negatives or missing) & TN (true negatives or correct rejections) & FN + TN \\
Total & TP + FN & FP + TN & TP + FP + FN + TN $=T$ \\
\hline
\end{tabular}

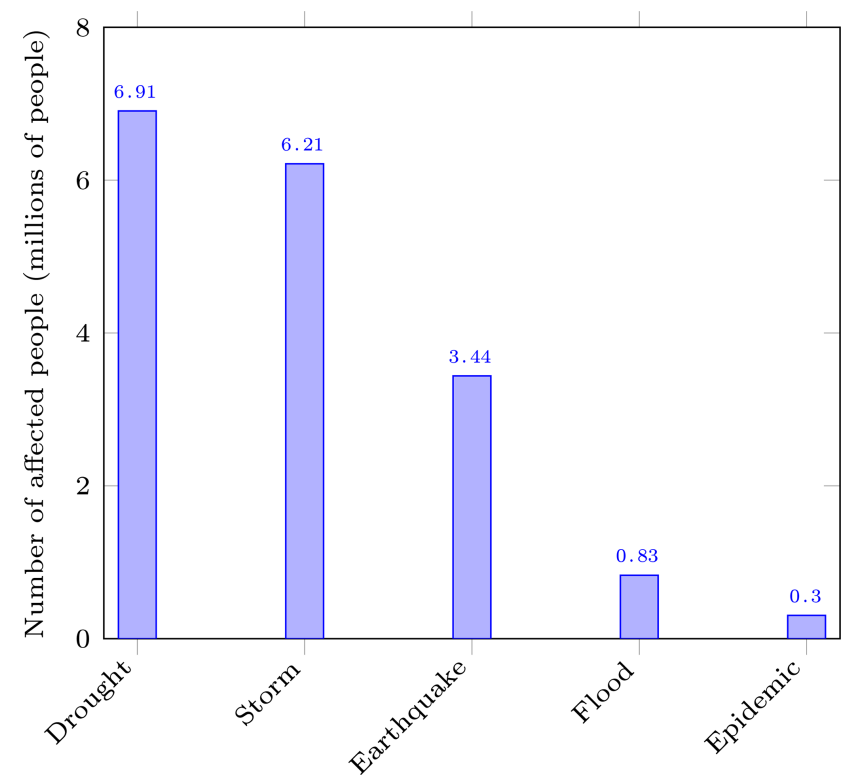

Figure 3. Number of people affected by natural disasters in Haiti (1900-2018). Source: CRED (2017).

Droughts threaten the livelihoods of Haitians in many different ways. The scarcity of crops production means a rise in food prices that brings widespread food insecurity since the majority of people cannot afford the increase. Unavailability of drinking water leads to cholera outbreaks among the population. Water is also an issue for breeders, who lose livestock on which they rely for milk production and meat consumption. In the period from 1980 to the present, more than 10 drought events have been reported by the government or the humanitarian organizations working in Haiti (Table 7). The worst drought was the one of 2014-2017, affecting more than 3 million inhabitants (about one-third of Haiti's population).

Effective drought management is crucial for Haiti, but at present, a reliable early-warning system for drought is still lacking. Weather stations on the ground are few and data records are often very short and therefore not useful for drought monitoring of the entire country. Satellite images can be an effective and inexpensive tool to improve drought management and preparedness in the country.

\section{Results and discussion}

\subsection{Correlation analysis}

Haiti has been divided into 987 grid cells, accounting for $90 \%$ of the country's area. A total of 1941 weeks were considered, starting from week 35 of 1981 and ending with week 52 of 2018. The release date of a new VHI image was considered as the starting date of a week. In the present study, four precipitation aggregation periods were considered $(1,2$, 3 and 6 months), and the corresponding values of SPI (SPI1, SPI2, SPI3 and SPI6) were computed in order to select the SPI aggregation timescale to be used to create the PPVI.

To evaluate the strength of the statistical relationship between the SPI at various timescales and the VHI, a correlation analysis was then performed. Various studies have already evaluated the correlation among drought indices or between drought indices and exogenous variables; for example Bonaccorso et al. (2015) investigated the correlation between the SPI and North Atlantic oscillation (NAO), while Hongshuo et al. (2014) investigated the correlation between the SPI (various aggregation periods) and the VHI. The Pearson correlation coefficient was employed in the present study as a measure of the statistical relationship between the indices. The number of significant correlations at $5 \%$ and $1 \%$ was evaluated for four SPI aggregation timescales (Table 8). The highest number of significant correlations was found in the cases of the SPI2 and SPI3, which exhibit very similar performances at a $1 \%$ significant level. This finding is in agreement with previous studies such as those of Hongshuo et al. (2014), which found that the VHI and SPI3 have the highest correlation with croplands, whereas the VHI and 6-month SPI have the highest correlation with forest in the southwest of China, and Ma'rufah et al. (2017), which found that significant correlation coefficient values of the SPI3 and VHI are common in the southern part of Indonesia. Since the SPI3 has been used in the literature and the percentage of significant correlation at the $1 \%$ level is relevant, it has been decided to aggregate the SPI over a 3-month period and use SPI3 in the following discussion.

\subsection{Normality of SPI and VHI distributions}

Before computing PPVI as described in the previous sections, a test on the normality of the SPI3 and $\mathrm{VHI}_{\text {st }}$ distri- 
Table 7. Reported drought events in Haiti from 1980 to the present.

\begin{tabular}{|c|c|c|c|c|}
\hline Year & Department & Affected people & Population (\%) & Source \\
\hline 1981 & Sud, Grand'Anse, Ouest & 103000 & 2 & $\begin{array}{l}\text { Mora-Castro (1986); CIAT } \\
\text { (2017) }\end{array}$ \\
\hline $1982-1983$ & $\begin{array}{l}\text { Sud, Sud-Est, Nord-Ouest, } \\
\text { Nord-Est }\end{array}$ & 333000 & 5.75 & $\begin{array}{l}\text { Sergio Mora-Castro, personal } \\
\text { communication, } 2018\end{array}$ \\
\hline 1984-1985 & Nord-Ouest & 13500 & 2 & $\begin{array}{l}\text { Mora-Castro (1986); CIAT } \\
\text { (2017) }\end{array}$ \\
\hline 1986 & All country & & & $\begin{array}{l}\text { Sergio Mora-Castro, personal } \\
\text { communication, } 2018\end{array}$ \\
\hline 1990-1992 & All country & 1000000 & 14 & $\begin{array}{l}\text { Sergio Mora-Castro, personal } \\
\text { communication, } 2018\end{array}$ \\
\hline 1997 & Nord-Ouest, Nord, Nord-Est & 50000 & 0.64 & CIAT (2017) \\
\hline 2000 & All country & & & $\begin{array}{l}\text { Sergio Mora-Castro, personal } \\
\text { communication, } 2018\end{array}$ \\
\hline 2003 & Nord-Ouest & 35000 & 0.41 & CIAT $(2017)$ \\
\hline End of 2009 & North West & & & $\begin{array}{l}\text { CNSA/MARNDR and FEWS- } \\
\text { NET (2009) }\end{array}$ \\
\hline 2011-2012 & $\begin{array}{l}\text { Nord, Nord-Ouest, Nord-Est, } \\
\text { Artibonite, Centre }\end{array}$ & & & $\begin{array}{l}\text { USAID et al. (2011); USAID } \\
\text { and FEWSNET (2012a) }\end{array}$ \\
\hline 2013 & All country & $>143000$ & 1.5 & $\begin{array}{l}\text { NOAA et al. (2013); FEWS- } \\
\text { NET (2013) }\end{array}$ \\
\hline 2014-2017 & All country & 3600000 & 33 & $\begin{array}{l}\text { OXFAM and Action contre la } \\
\text { Faim (2015); NOAA (2017) }\end{array}$ \\
\hline
\end{tabular}

Table 8. Number of significant correlations (Pearson correlation coefficient) between VHI and various SPI aggregation timescales. Values are expressed as percentages evaluated with respect to the total number of grid cells (987).

\begin{tabular}{ccc}
\hline & $\begin{array}{c}\text { Significant correlations } \\
\text { at } 5 \%(\%)\end{array}$ & $\begin{array}{c}\text { Significant correlations } \\
\text { at } 1 \%(\%)\end{array}$ \\
\hline SPI1 & 93.52 & 91.29 \\
SPI2 & 96.76 & 95.34 \\
SPI3 & 96.15 & 94.83 \\
SPI6 & 90.07 & 85.82 \\
\hline
\end{tabular}

butions was performed. The goodness of fit of the SPI3 and the $\mathrm{VHI}_{\text {st }}$ distributions was verified through the histograms in Fig. 4 (panels a and b respectively), where the boxplots represent the relative frequencies of the SPI3 and $\mathrm{VHI}_{\mathrm{st}}$ values. Both the SPI3 and the $\mathrm{VHI}_{\text {st }}$ data can therefore be considered normally distributed.

\subsection{Selection of threshold values}

The PPVI was computed as described in Sect. 2.2, and its performance in identifying past drought events in Haiti when used in combination with the set of rules described in Sect. 2.2.4 was evaluated. To this end, the ROC curve classification methodology was applied. The set of rules meant that, at first, cells in drought conditions were identified: drought started in a specific grid cell at week $W$ when the PPVI was
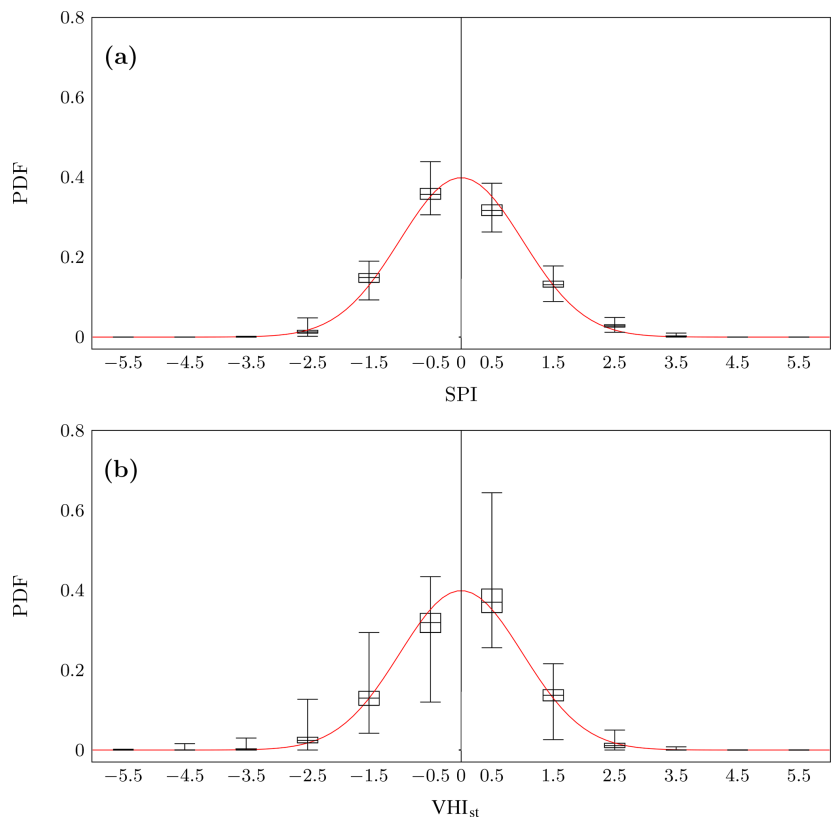

Figure 4. (a) Distribution of SPI values and (b) distribution of $\mathrm{VHI}_{\text {st }}$ values. The red lines represent the PDFs of the standard normal distributions; boxplots represent the percentage of values lying within the range; 12 ranges were considered, starting from -6 and ending with 6 with a step equal to 1 . 
lower than the threshold $Z$ and ended when the PPVI was up to the threshold $z$ in the same grid cell at a week $w$ (with $w$ coming after $W$ ). Then a regional drought event was identified: the drought event started when more than $N$ cells at a specific week $W_{1}$ were in drought conditions and ended at a week $W_{2}$ when fewer than $n$ grid cells were in drought conditions. The comparison was performed on a weekly basis, with observations derived from the reported events described in Table 7.

The ROC curves were computed according to the following methodology: at first a combination of the thresholds $Z$, $z, N$ and $n$ was selected. On the basis of the set of rules established in Sect. 2.2.4, the ability of the selected combination of thresholds in reproducing the observations was assessed by computing TP, TN, FP and FN as defined in Table 6, together with POD and POFD. A couple (POFD, POD) represents a point in a ROC graph. Then one threshold among $Z$, $z, N$ and $n$ was selected. The selected threshold was variable during the analysis, while the other three were kept constant. The step of variation was identified according to the threshold maximum and minimum values. For each combination of the four thresholds (the varying one and the three fixed), TP, TN, FP, FN, and POD and POFD were computed. The resulting set of couples (POFD, POD) represented the ROC curve for the considered set of thresholds.

The analysis was repeated by varying another threshold among $Z, z, N$ and $n$. As an example, Fig. 5 shows four ROC curves for the thresholds in Table 9. Thresholds $N$ and $n$ in Table 9 are expressed as the percentage of the country's area instead of as the number of grid cells. For each of the curves the best-performing set of thresholds $(Z, z, N$ and $n)$ was selected by identifying the point farthest from the $45^{\circ}$ line, as performed by Zhu et al. (2016). The area under the curve (AUC) was used as a criterion to establish which of the ROC curves should be preferred (as was performed by Dutra et al., 2014; Mason and Graham, 2002; Zhu et al., 2012). An AUC near to 1 indicates good performance, while an AUC of 0.5 indicates the model has no predictive skills. From Fig. 5 it is clear that the curve corresponding to the parameters defined as Set 2 in Table 9 should be preferred, since the AUC is the closest to 1 .

\subsection{Comparison of drought indices with observed drought events}

The aim of this section is not to validate in absolute terms the proposed methodology since the data record is too short to serve both for calibration and for validation. In the present section, instead, we provide a validation by comparing the performance of the PPVI in identifying observed drought events with those of widely recognized and used indices such as the SPI and VHI.

The performance of the PPVI was then compared to those of the SPI3 and VHI considered separately. Thresholds analogous to $Z$ and $z$ were defined for the SPI3 and VHI. Thresh-

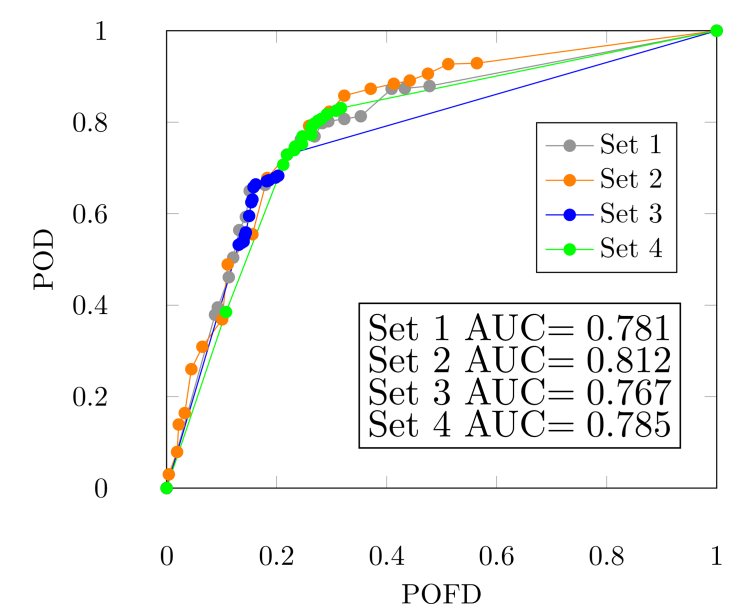

Figure 5. ROC curves for the set of thresholds reported in Table 9.

olds $Z_{S}$ and $z_{S}$ mark respectively the beginning and the end of drought conditions in a grid cell according to the SPI3, and thresholds $Z_{V}$ and $z_{V}$ do the same in the case of the VHI. Again the four thresholds $Z, z, N$, and $n$ were varied in order to identify the optimal values. As an example, Fig. 6 shows a comparison among the ROC curves for the three indices. In each panel of Fig. 6, $n$ and $z$ and $z_{S}$ and $z_{V}$ (for PPVI, SPI3 and VHI) remained constant, while $Z, Z_{S}$ and $Z_{V}$ were varying; $N$ was fixed in each panel but varied between the panels. $Z$ varied from -4 to -1.1 with a step equal to $0.1 ; Z_{S}$ varied from -3 to 0 with a step equal to 0.1 , and $Z_{V}$ varied from 10 to 40 with a step equal to 5 .

It is clear from Fig. 6 that the red curve, representing the PPVI, is the furthest from the diagonal line in all the panels of the figure. The area under the curve (AUC) was used as a criterion to establish which index gave the best performances. AUC values are shown in Fig. 6 for each index and various configurations of the model. The AUC value of the PPVI was in line with similar results reported in the literature (Mwangi et al., 2014). As can be seen from Fig. 6, the new index provided better results with respect to the ones obtained with the SPI3 or VHI considered separately. In all the four configurations shown in Fig. 6, the AUC for the curve constructed with the PPVI was larger than the ones for the SPI3 and VHI. The AUC values are in line with the ones considered good in the literature for drought predictive skills (see Khadr, 2016). The optimal thresholds to configure the model when applied with each of the three considered indices were then determined by selecting the point farthest from the $45^{\circ}$ line, as performed by Zhu et al. (2016). The best configuration parameters are shown in Table 10. The drought events were therefore identified using the optimal parameters (Table 10). A graphical representation of the performance of the model in reproducing observed drought events is given in Fig. 7. Only the period from 2000 to 2018 is shown.

The ability of the model in identifying the country area hit by the drought was also assessed. A visual comparison of 
Table 9. Example of set of thresholds used to draw ROC curves for model calibration. Thresholds $N$ and $n$ are expressed as the percentage of the country's area instead of as the number of grid cells.

\begin{tabular}{llllll}
\hline & $Z$ & $z$ & $N$ & $n$ & Step of variation \\
\hline Set 1 & -2 & varying from -1.9 to 0 & $25 \%$ & $10 \%$ & 0.1 \\
Set 2 & varying from -3.5 to -1 & -1 & $25 \%$ & $10 \%$ & 0.1 \\
Set 3 & -2 & -1 & $25 \%$ & varying from $1 \%$ to $24 \%$ & $1 \%$ \\
Set 4 & -2 & -1 & varying from $11 \%$ to $25 \%$ & $10 \%$ & $1 \%$ \\
\hline
\end{tabular}
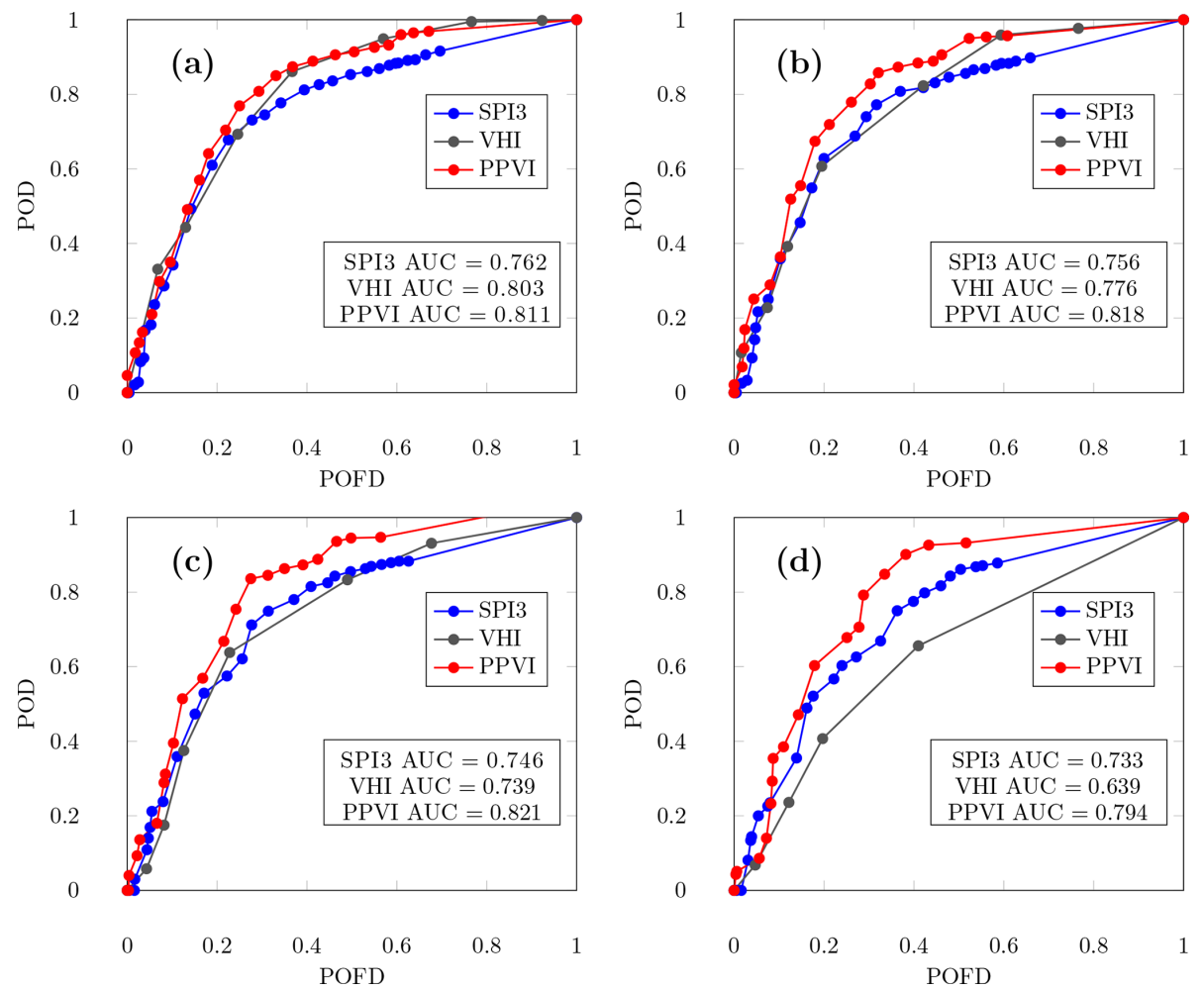

Figure 6. Comparison between the performances of the SPI3, VHI and PPVI in identifying reported drought events; thresholds $Z, Z_{S}$ and $Z_{V}$ are varying; $z=-1.1 ; z_{S}=0$, and $z_{V}=40 ; n=80$, and four cases for $N$ are shown. (a) $N=10 \% ;(\mathbf{b}) N=20 \% ;(\mathbf{c}) N=30 \%$; and (d) $N=50 \%$.

the areas under drought identified by the three indices was performed, as was performed by Dutta et al. (2015).

Here some significant weeks are shown. At first, week 45 of 1995 was considered. No drought events were reported in that period according to the information available in the analysed documents (see Table 7). Figure 8 shows that, while the SPI3 identified the whole southern part of the country as dry areas and the VHI showed vegetation suffering in two departments (Centre and Ouest), the PPVI did not show signs of drought, except for in a minor number of grid cells. Figure 9 shows that in 2015, when the whole country was reported to be in severe drought conditions (see Table 7 and NOAA, 2017; OXFAM and Action contre la Faim, 2015), the PPVI captured the pattern well; only a few grid cells were not in drought conditions. The SPI3 was also able to capture the situation, while for the VHI only $58 \%$ of the county was in drought. During week 8 of 2012, only the northern part of the country was in drought (Fig. 10), as highlighted by USAID and FEWSNET (2012b) (see Table 7). Five departments were reported to be stressed (Nord, Nord-Ouest, NordEst, Artibonite, Centre; see Table 7). All the three indices showed the Nord-Ouest as the department most affected by drought when considering the percentage of the department area hit by the drought. The PPVI then classified Artibonite, Nord, Centre and Nord Est as the next most affected, while the SPI3 identified Sud and Grand'Anse as the second- and third-most-affected departments and the VHI identified Centre and Nippes (Table 11).

Severity, duration and mean areal extent of the drought events identified by the PPVI were computed. Severity was computed as the sum of all the values identified by the condition that a grid cell is in a drought condition when the PPVI 
Table 10. Best configuration parameters for the model when applied with the PPVI, SPI3 and VHI.

\begin{tabular}{lrrcccccccc}
\hline & $Z$ & $z$ & $N$ & $n$ & TN & FP & FN & TP & POFD & POD \\
\hline PPVI & -1.8 & -1.1 & $30 \%$ & $8 \%$ & 957 & 379 & 99 & 506 & 0.284 & 0.836 \\
SPI3 & -1.3 & 0 & $20 \%$ & $8 \%$ & 943 & 393 & 157 & 448 & 0.294 & 0.749 \\
VHI & 22 & 40 & $10 \%$ & $8 \%$ & 935 & 401 & 150 & 455 & 0.300 & 0.752 \\
\hline
\end{tabular}

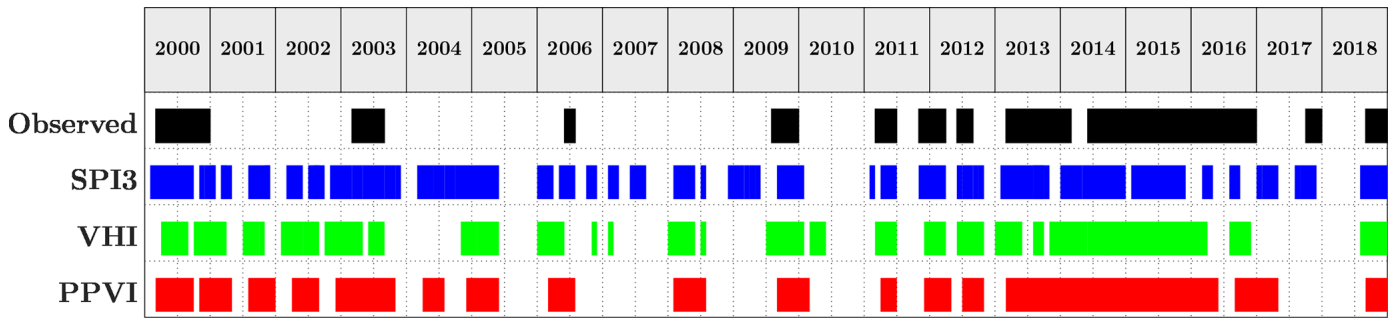

Figure 7. Comparison between observed drought events and drought events identified by the PPVI, SPI3 and VHI when calibrated with the best-performing parameters shown in Table 10. The comparison is shown for the period from 2000 to 2018.

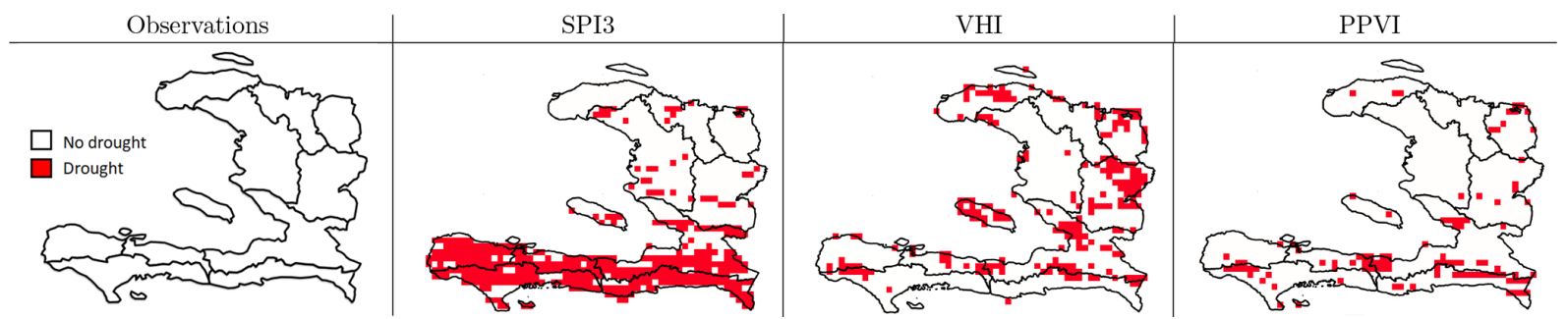

Figure 8. Comparison of the performance of the SPI3, VHI, and PPVI in identifying the areas hit by drought in week 45 of 1995 . Departments highlighted in red are the ones in drought according to observations (Table 7); red cells are the ones in drought conditions according to the various indices.

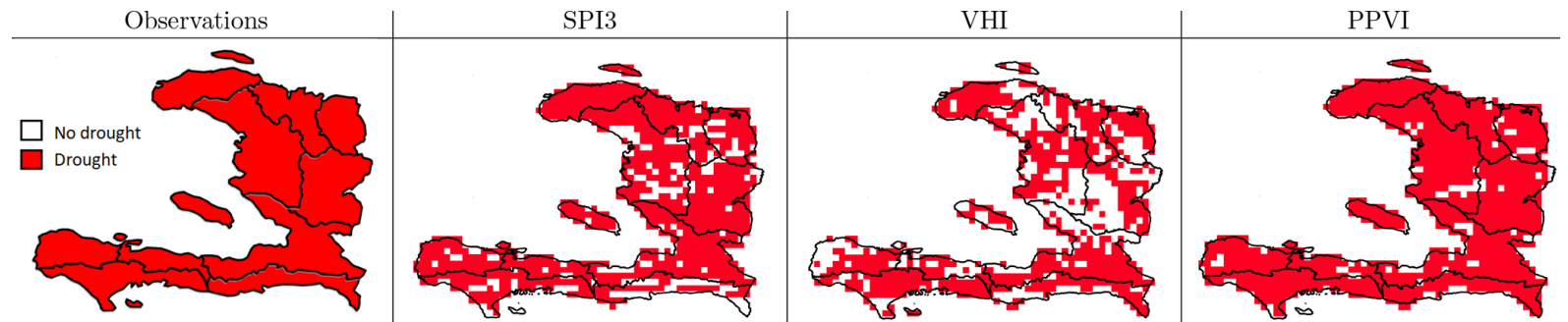

Figure 9. Same as Fig. 8 but for week 33 of 2015. Departments highlighted in red are the ones in drought according to observations; red cells are the ones in drought conditions according to the various indices.

is lower than -1.8 and exits from drought when the PPVI is up to -1.1 . Duration is expressed in months, and the mean areal extent is the average percentage of the area in drought during a specific event. Results are presented in Table 12.

The PPVI showed overall a better capacity in identifying drought events with respect to the SPI3 and VHI considered separately. However, some false alarms still remain. This can be linked to the uncertainty in information on past drought events for the analysed area. Short-term droughts are often not reported in text-based documents, and information on drought start and end dates was retrieved from documents that mainly described the impacts related to drought. The PPVI showed a good agreement with reported information in identifying the areas of the country hit by droughts.

\section{Conclusions}

The timely identification of drought events is of great importance in agricultural areas, especially when rainfed agriculture is practised. At the same time, the evaluation of the damage caused by drought is a key point to select appropri- 


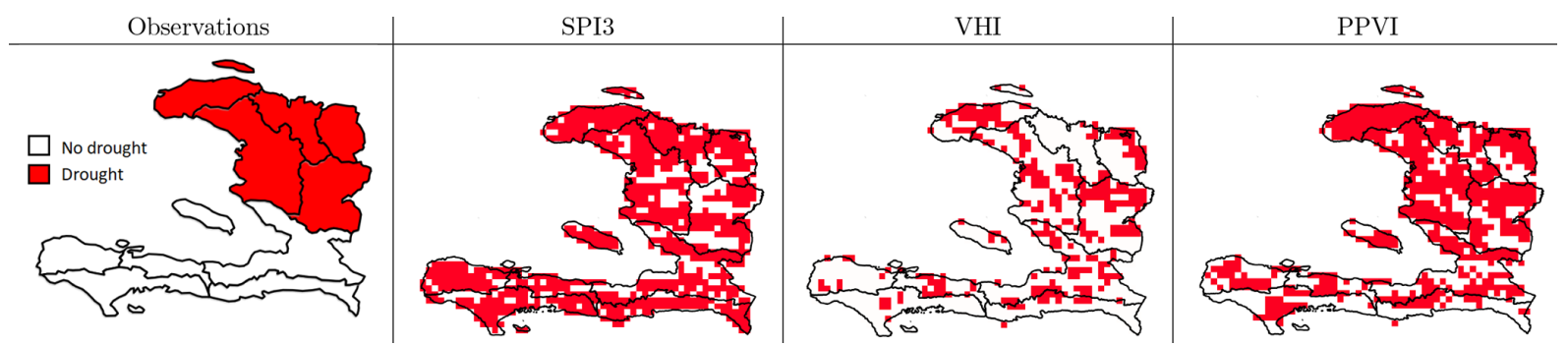

Figure 10. Same as Fig. 8 but for week 8 of 2012. Departments highlighted in red are the ones in drought according to observations; red cells are the ones in drought conditions according to the various indices.

Table 11. Performance of the PPVI, SPI3 and VHI in identifying departments hit by drought during week 8 of 2012 and comparison with observations. Observations are retrieved from the text-based documents reported in Table 7.

\begin{tabular}{|c|c|c|c|c|c|c|c|}
\hline \multirow[b]{2}{*}{ Department } & \multirow{2}{*}{$\begin{array}{l}\text { Reported } \\
\text { as drought }\end{array}$} & \multicolumn{3}{|c|}{ Areal extent (\%) } & \multicolumn{3}{|c|}{$\begin{array}{c}\text { Ranking of affected } \\
\text { departments }\end{array}$} \\
\hline & & PPVI & SPI3 & VHI & PPVI & SPI3 & VHI \\
\hline Nord-Ouest & Yes & 93.1 & 91.7 & 47.2 & 1 & 1 & 1 \\
\hline Artibonite & Yes & 75.1 & 72.8 & 34.1 & 2 & 7 & 5 \\
\hline Nord & Yes & 74.6 & 82.1 & 10.4 & 3 & 4 & 9 \\
\hline Centre & Yes & 67.2 & 54.3 & 45.7 & 4 & 10 & 2 \\
\hline Nord-Est & Yes & 62.1 & 72.4 & 34.5 & 5 & 8 & 4 \\
\hline Ouest & No & 61.8 & 72.1 & 32.7 & 6 & 9 & 6 \\
\hline Nippes & No & 51.2 & 75.6 & 36.6 & 7 & 5 & 3 \\
\hline Grand'Anse & No & 47.8 & 82.1 & 10.4 & 8 & 3 & 8 \\
\hline Sud & No & 32.6 & 75.3 & 9 & 9 & 6 & 10 \\
\hline Sud-Est & No & 30.8 & 84.6 & 20 & 10 & 2 & 7 \\
\hline
\end{tabular}

ate risk management strategies, such as weather index insurance programmes, agricultural index insurance, disaster financing and early action planning. The new composite index proposed in this paper, the probabilistic precipitation vegetation index, PPVI, is a powerful tool since it can identify events of vegetation stress and, at the same time, select from among those the ones actually due to drought, thanks to the use of both the VHI and the SPI. As such it can be helpful in agricultural drought monitoring and can be used to identify drought events affecting a region, their severity and their duration as was shown in the case of Haiti. In particular, the PPVI can be invaluable in those areas where rainfed agriculture is of vital importance since people rely on it for food production for personal consumption.

Among the interesting aspects of the PPVI, there is the fact that few data are required for its computation: only precipitation and the VHI. This aspect is crucial, since many composite indicators able to identify agricultural droughts already exist, but large quantities of data are required to compute them. For example, the United States Drought Monitor combines more than 40-50 inputs, while other indices specific to agricultural drought monitoring, such as the VegDRI and the VegOut, require the use of temperature and oceanic indices.
The number of parameters required to compute the PPVI is low even with respect to the OBDI, SWS, CDI or CDSI.

A second important advantage is that, since the SPI was computed starting from satellite precipitation (CHIRP dataset) and that the VHI is a remote-sensing drought index, the PPVI is also a remote-sensing product. The use of datasets with global coverage means that the PPVI is easily transferable and scalable over the entire globe. In addition, the PPVI can be a very useful tool in areas with scarce gauge coverage such as the Caribbean islands. Both precipitation and the VHI have a very high spatial and temporal resolution, thus allowing drought monitoring via satellite even in small areas. The PPVI can be computed even in those regions with short data records, since the VHI has more than 30 years of records (data collection began in August 1981) and CHIRP precipitation is available from January 1981.

Both the SPI and the VHI are updated with a weekly time step since every week a new VHI image is released, and the CHIRP precipitation dataset has a daily temporal resolution; therefore the PPVI can be updated more frequently than other composite indices, such as the CDI, which is updated every $10 \mathrm{~d}$. In addition, due to the relatively short latency time (less than 1 week) of both the datasets employed to create the PPVI, the index is available in near real time, therefore 
Table 12. Drought events in Haiti according to the PPVI, duration, severity and mean areal extent.

\begin{tabular}{|c|c|c|c|c|c|c|}
\hline $\begin{array}{l}\text { Event } \\
\text { number }\end{array}$ & Start date & End date & $\begin{array}{l}\text { Duration } \\
\text { (months) }\end{array}$ & $\begin{array}{c}\text { Mean } \\
\text { intensity PPVI }\end{array}$ & $\begin{array}{l}\text { Minimum } \\
\text { PPVI }\end{array}$ & $\begin{array}{l}\text { Mean areal } \\
\text { extent }(\%)\end{array}$ \\
\hline 1 & 22 Apr 1982 & $21 \mathrm{Jul} 1983$ & 15 & -8.46 & -4.73 & 32.13 \\
\hline 2 & 27 Dec 1984 & 7 Nov 1985 & 11 & -7.87 & -3.91 & 49.60 \\
\hline 3 & 18 Sep 1986 & 16 Apr 1987 & 7 & -7.90 & -3.62 & 41.65 \\
\hline 4 & 16 Nov 1989 & 18 Oct 1990 & 11 & -8.60 & -4.59 & 35.48 \\
\hline 5 & 7 Feb 1991 & 11 Feb 1993 & 25 & -8.70 & -4.69 & 44.92 \\
\hline 6 & 16 Sep 1993 & 27 Jan 1994 & 4 & -8.95 & -4.48 & 36.98 \\
\hline 7 & 11 Aug 1994 & 10 Nov 1994 & 3 & -8.53 & -3.50 & 50.11 \\
\hline 8 & 20 Mar 1997 & 20 Nov 1997 & 8 & -8.43 & -4.32 & 46.00 \\
\hline 9 & 30 Mar 2000 & 21 Oct 2000 & 6 & -8.31 & -3.79 & 74.07 \\
\hline 10 & 30 Nov 2000 & 19 Apr 2001 & 5 & -7.98 & -4.75 & 24.58 \\
\hline 11 & 9 Aug 2001 & 6 Dec 2001 & 4 & -7.85 & -3.52 & 30.23 \\
\hline 12 & 4 Apr 2002 & 8 Aug 2002 & 4 & -8.25 & -3.47 & 26.20 \\
\hline 13 & 19 Dec 2002 & 30 Oct 2003 & 11 & -7.72 & -3.44 & 29.31 \\
\hline 14 & 15 Apr 2004 & 22 Jul 2004 & 3 & -7.69 & -3.37 & 17.89 \\
\hline 15 & 2 Dec 2004 & 26 May 2005 & 6 & -9.00 & -4.40 & 79.00 \\
\hline 16 & 23 Mar 2006 & 13 Jul 2006 & 4 & -7.46 & -3.43 & 22.97 \\
\hline 17 & 21 Feb 2008 & 31 Jul 2008 & 5 & -7.95 & -3.78 & 30.07 \\
\hline 18 & 17 Sep 2009 & 18 Feb 2010 & 5 & -8.58 & -3.95 & 57.48 \\
\hline 19 & 21 Apr 2011 & 16 Jun 2011 & 2 & -9.32 & -4.14 & 48.28 \\
\hline 20 & 29 Dec 2011 & 5 Apr 2012 & 3 & -8.12 & -3.91 & 62.52 \\
\hline 21 & 19 Jul 2012 & 25 Oct 2012 & 3 & -8.33 & -3.62 & 42.16 \\
\hline 22 & 7 Mar 2013 & 5 May 2016 & 39 & -8.18 & -4.00 & 34.50 \\
\hline 23 & 29 Sep 2016 & 20 Apr 2017 & 7 & -8.20 & -4.06 & 15.02 \\
\hline 24 & 12 Jul 2018 & 31 Dec 2018 & 6 & -9.50 & -5.58 & 58.50 \\
\hline
\end{tabular}

allowing for the timely implementation of drought mitigation strategies. This last feature is of particular interest when the PPVI is used to implement measures to reduce drought risk in agriculture, where a timely identification of drought is crucial to prevent damage to the sector.

Many advantages are also related to the adoption of the set of rules here proposed to identify drought events. First of all, these rules enable an objective and standardized identification of drought events from the mathematical point of view. Additionally, they can be adjusted according to the needs and the objectives of various possible end users of the model, such as farmers, governments or insurance companies.

The performances of the PPVI in identifying drought events were tested in a specific case study (Haiti) and compared to the ones of the SPI and VHI considered separately. The PPVI performed better than the single indices considered separately in reproducing past drought events. The PPVI identified drought areas in Haiti better than the SPI and VHI even from the spatial point of view; thus it is more reliable than a single index. A comparison of PPVI performances with respect to the ones of other composite indices was not performed in the present study due to the unavailability of composite indices with the same characteristics of the PPVI. In fact previous composite indices do not include both the meteorological and the agricultural aspect of drought, are not available globally, or cannot be computed with only remotesensing datasets.

Data availability. Both CHIRP and the NOOA VHI dataset are freely available at the links cited in the references.

Author contributions. This research is part of the $\mathrm{PhD}$ thesis of BM. Both $\mathrm{BB}$ and $\mathrm{MM}$ were the thesis supervisors.

Competing interests. The authors declare that they have no conflict of interest.

Special issue statement. This article is part of the special issue "Recent advances in drought and water scarcity monitoring, modelling, and forecasting (EGU2019, session HS4.1.1/NH1.31)". It is a result of the European Geosciences Union General Assembly 2019, Vienna, Austria, 7-12 April 2019.

Acknowledgements. The research leading to these results has received funding from the Disaster Risk Financing Challenge Fund of the World Bank Group in the context of the SMART (a statistical, machine learning framework for parametric risk transfer) 
project. The research has been developed within the framework of the project Dipartimenti di eccellenza, funded by the Italian Ministry of Education, University and Research at IUSS Pavia.

Review statement. This paper was edited by Athanasios Loukas and reviewed by two anonymous referees.

\section{References}

Bachmair, S., Stahl, K., Collins, K., Hannaford, J., Acreman, M., Svoboda, M., Knutson, C., Smith, K. H., Wall, N., Fuchs, B., Crossman, N. D., and Overton, I. C.: Drought indicators revisited: the need for a wider consideration of environment and society, Wiley Rev.: Water, 3, 516-536, https://doi.org/10.1002/wat2.1154, 2016.

Barnett, B. J. and Mahul, O.: Weather Index Insurance for Agriculture and Rural Areas in Lower-Income Countries, Am. J. Agric. Econ., 89, 1241-1247, 2007.

Bateni, M., Behmanesh, J., and Bazrafshan, J.: Composite Agrometeorological Drought Index Accounting for Seasonality and Autocorrelation, J. Hydrol. Eng., 23, https://doi.org/10.1061/(ASCE)HE.1943-5584.0001654, 2018.

BC Ministry for Agriculture: Soil water storage capacity and available soil moisture, Tech. rep., British Columbia Ministry of Agriculture, Abbotsford, British Columbia, 2015.

Bergman, K., Sabol, P., and Miskus, D.: Experimental Indices for monitoring global drought conditions, Proceedings of 13th Annual Climate Diagnostics Workshop, US Department of Commerce, National Oceanic and Atmospheric Administration, Cambridge, Massachusetts, 1988.

Bijaber, N., Hadani, D. E., Saidi, M., Svoboda, M. D., Wardlow, B. D., Hain, C. R., Poulsen, C. C., Yessef, M., and Rochdi, A.: Developing a Remotely Sensed Drought Monitoring Indicator for Morocco, Geosciences, 8, 1-18, https://doi.org/10.3390/geosciences8020055, 2018.

Bonaccorso, B., Cancelliere, A., and Rossi, G.: Methods for Drought Analysis and Forecasting, in: Handbook of Methods and Applications of Statistics in the Atmospheric and Earth Sciences, John Wiley \& Sons, Inc., New York, 150-184, 2012.

Bonaccorso, B., Cancelliere, A., and Rossi, G.: Probabilistic forecasting of drought class transitions in Sicily (Italy) using Standardized Precipitation Index and North Atlantic Oscillation Index, J. Hydrol., 526, 136-150, https://doi.org/10.1016/j.jhydrol.2015.01.070, 2015.

Brown, J. F., Wardlow, B. D., Tadesse, T., and Hayes, M. J.: The Vegetation Drought Response Index (VegDRI): A New Integrated Approach for Monitoring Drought Stress in Vegetation, GISci. Remote Sens., 45, 16-46, https://doi.org/10.2747/15481603.45.1.16, 2008.

CIAT: Atlas des menaces naturelles en Haiti, Tech. rep., http: //ciat.gouv.ht/articles/atlas-des-menaces-naturelles-en-haiti (last access: 18 November 2019), 2017.

Climate Hazard Group: Climate Hazard Group InfraRed Precipitation data archive, available at: ftp://ftp.chg.ucsb.edu/pub/org/chg/ products/CHIRP/ (last access: 15 December 2019), 1999.
Climate Hazard Group: Chirp daily, available at: ftp://ftp.chg.ucsb. edu/pub/org/chg/products/CHIRP/daily/ (last access: 15 December 2019), 2015.

CNSA/MARNDR and FEWSNET: Haiti Food Security Update September 2009, available at: https://reliefweb.int/report/ haiti/haiti-food-security-update-april-september-2009 (last access: 15 July 2019), 2009.

CRED: EM-DAT The International Disaster Database, available at: http://emdat.be/emdat_db/ (last access: 15 July 2019), 2017.

Dalezios, N. R., Tarquis, A. M., and Eslamian, S.: Droughts, in: Environmental Hazards Methodologies for Risk Assessment and Management, chap. 5, edited by: Dalezios, N. R., IWA Publishing, London, https://doi.org/10.2166/9781780407135, 2017.

Dieker, E., van Lanen, H. A. J., and Svoboda, M.: Comparison of Three Drought Monitoring Tools in the USA, WATCH Technical Report No. 25, 86 pp., available at: http://www.eu-watch.org/ media/default.aspx/emma/org/10653999/ (last access: 14 February 2020), 2010.

Drechsler, M. and Soe, W.: Early Warning, Early Action. The Use of Predictive Tools in Drought Response through Ethiopia's Productive Safety Net Programme, Tech. Rep. June, $36 \mathrm{pp}$., available at : http://documents.worldbank.org/curated/en/346411468188663 (last access: 14 February 2020), 2016.

Dutra, E., Pozzi, W., Wetterhall, F., Di Giuseppe, F., Magnusson, L., Naumann, G., Barbosa, P., Vogt, J., and Pappenberger, F.: Global meteorological drought - Part 2: Seasonal forecasts, Hydrol. Earth Syst. Sci., 18, 2669-2678, https://doi.org/10.5194/hess-182669-2014, 2014.

Dutta, D., Kundu, A., Patel, N., Saha, S., and Iddiqui, A.: Assessment of agricultural drought in Rajasthan (India) using remote sensing derived Vegetation Condition Index (VCI) and Standardized Precipitation Index (SPI), Egypt. J. Remote Sens. Space Sci., 18, 53-63, https://doi.org/10.1016/j.ejrs.2015.03.006, 2015.

FEWSNET: HAITI Food Security Outlook Update May 2013, Tech. Rep. May, available at: https://reliefweb.int/report/ haiti/haiti-food-security-outlook-update-may-2013 (last access: 25 July 2019), 2013.

FEWSNET: Haiti seasonal calendar, available at: http://fews.net/ central-america-and-caribbean/haiti, 2019.

Funk, C., Peterson, P., Landsfeld, M., Pedreros, D., Verdin, J., Shukla, S., Husak, G., Rowland, J., Harrison, L., Hoell, A., and Michaelsen, J.: The climate hazards infrared precipitation with stations - A new environmental record for monitoring extremes, Sci. Data, 2, 1-21, https://doi.org/10.1038/sdata.2015.66, 2015.

GFDRR: Climate Risk and Adaptation Country Profile: vulnerability, risk reduction and adaptation to climate change in Haiti, Tech. Rep. April, 12 pp., available at: https://www.gfdrr.org/sites/default/files/publication/ climate-change-country-profile-2011-haiti.pdf (last access: 14 February 2020), 2011.

Gu, Y., Hunt, E., Wardlow, B., Basara, J. B., Brown, J. F., and Verdin, J. P.: Evaluation of MODIS NDVI and NDWI for vegetation drought monitoring using Oklahoma Mesonet soil moisture data, Geophys. Res. Lett., 35, 1-5, https://doi.org/10.1029/2008GL035772, 2008.

Guimarães Nobre, G., Davenport, F., Bischiniotis, K., Veldkamp, T., Jongman, B., Funk, C. C., Husak, G., Ward, P. J., and Aerts, J. C. J. H.: Financing agricultural drought risk through 
ex-ante cash transfers, Sci. Total Environ., 653, 523-535, https://doi.org/10.1016/j.scitotenv.2018.10.406, 2019.

Hao, Z. and Aghakouchak, A.: Advanc es in Water Resou rces Multivariate Standardized Drought Index: A parametric multi-index model, Adv. Water Resour., 57, 12-18, https://doi.org/10.1016/j.advwatres.2013.03.009, 2013.

Hao, Z. and Singh, V. P.: Drought characterization from a multivariate perspective: A review, J. Hydrol., 527, 668-678, https://doi.org/10.1016/j.jhydrol.2015.05.031, 2015.

Hao, Z. and Singh, V.: Review of dependence modeling in hydrology and water resources, Prog. Phys. Geog., 40, 549-578, https://doi.org/10.1177/0309133316632460, 2016.

Hongshuo, W., Hui, L., and Desheng, L.: Remotely sensed drought index and its responses to meteorological drought in Southwest China, Remote Sens. Lett., 5, 413-422, https://doi.org/10.1080/2150704X.2014.912768, 2014.

Idso, S., Jackson, R., Pinter, P. J., Reginato, R., and Hatfield, J.: Normalizing the stress-degree-day parameter for environmental variability, Agr. Meteorol., 24, 45-55, https://doi.org/10.1016/00021571(81)90032-7, 1981.

Jensen, N. and Barrett, C.: Agricultural Index Insurance for Development, Appl. Econ. Perspect. P., 39, 199-219, https://doi.org/10.1093/aepp/ppw022, 2017.

Joliffe, I. T. and Stephenson, D. B.: Forecast Verification: a practitioner's guide in Atmospheric Science, Int. Geophys., 100, 301-394, https://doi.org/10.1016/B978-0-12-385022-5.00008-7, 2012.

Kao, S.-C. and Govindaraju, R. S.: A copula-based joint deficit index for droughts, J. Hydrol., 380, 121-134, https://doi.org/10.1016/j.jhydrol.2009.10.029, 2010.

Karamouz, M., Rasouli, K., and Nazif, S.: Development of a Hybrid Index for Drought Prediction: Case Study, J. Hydrol. Eng., 14, 617-627, 2009.

Keyantash, J. and Dracup, J.: An aggregate drought index: Assessing drought severity based on fluctuations in the hydrologic cycle and surface water storage, Water Resour. Res., 40, W09304, https://doi.org/10.1029/2003WR002610, 2004.

Khadr, M.: Forecasting of meteorological drought using Hidden Markov Model (case study: The upper Blue Nile river basin, Ethiopia), Ain Shams Engin. J., 7, 47-56, https://doi.org/10.1016/j.asej.2015.11.005, 2016.

Kogan, F. N.: Remote sensing of weather impacts on vegetation in non-homogeneous areas, Int. J. Remote Sens., 11, 1405-1419, 1990.

Kogan, F. N.: Droughts of the late 1980s in the United States as derived from NOAA polarorbiting satellite data, B. Am. Meteorol. Soc., 76, 655-668, 1995a.

Kogan, F. N.: Application of vegetation index and brightness temperature for drought detection, Adv. Space Res., 15, 2761-2782, 1995b.

Kogan, F. N.: Global Drought Watch from Space, B. Am. Meteorol. Soc., 78, 621-636, 1997.

Kogan, F. N., Guo, W., Strashnaia, A. A. K., Chub, O., and Virchenko, O.: Modelling and prediction of crop losses from NOAA polar-orbiting operational satellites, Geomat. Nat. Haz. Risk, 7, 886-900, https://doi.org/10.1080/19475705.2015.1009178, 2016.
Kotz, S., Balakrishnan, N., and Johnson, N. L.: Continuous Multivariate Distributions, 2nd Edn., John Wiley \& Sons, New York, https://doi.org/10.1002/0471722065, 2000.

Lambin, E. and Ehrlich, D.: Combining vegetation indices and surface temperature for land-cover mapping at broad spatial scales, Int. J. Remote Sens., 16, 573-579, https://doi.org/10.1080/01431169508954423, 1995.

Linnerooth-Bayer, J. and Hochrainer-Stigler, S.: Financial instruments for disaster risk management and climate change adaptation, Climatic Change, 133, 85-100, https://doi.org/10.1007/s10584-013-1035-6, 2015.

Liu, W. and Kogan, F. N.: Monitoring regional drought using the Vegetation Condition Index, Int. J. Remote Sens., 17, 27612782, 1996.

Ma'rufah, U., Hidayat, R., and Prasati, I.: Analysis of relationship between meteorological and agricultural drought using standardized precipitation index and vegetation health index, in: Earth and Environmental Science, vol. 54, IOP Publishing, UK, p. 7, https://doi.org/10.1088/1742-6596/755/1/011001, 2017.

Mason, S. and Graham, N.: Area beneath the relative operating characteristics (ROC) and relative operating levels (ROL) curves: statistical significance and interpretation, Q. J. Roy. Meteorol. Soc., 128, 2145-2166, https://doi.org/10.1016/B978-1-43770795-3.00025-9, 2002.

Matera, A., Fontana, G., and Marletto, V.: Use Of a New Agricultural Drought Index Within a Regional Drought Observatory, in: Methods and Tools for Drought Analysis and Management, edited by: Rossi, G., Springer, the Netherlands, https://doi.org/10.1007/978-1-4020-5924-7, 103-124, 2007.

Mckee, T. B., Doesken, N. J., and Kleist, J.: The relationship of drought frequency and duration to time scales, in: AMS 8th Conference on Applied Climatology, January, 179-184, available at: https://www.droughtmanagement.info/literature/AMS_ Relationship_Drought_Frequency_Duration_Time_Scales_ 1993.pdf (ast access: 14 February 2020), 1993.

Meyer, S. J., Hubbard, K. G., and Wilhite, D. A.: Crop-Specific Drought Index for Corn: I. Model Development and Validation, Agron. J., 86, 388-395, https://doi.org/10.2134/agronj1993.00021962008500020040x, 1993.

Mora-Castro, S.: Etude de reconaissance sur les differents types des menaces naturelles dans le basin versant de l'Artibonite, Haiti, Tech. rep., Ingeosa, Port au Prince, 1986.

Mwangi, E., Wetterhall, F., Dutra, E., Di Giuseppe, F., and Pappenberger, F.: Forecasting droughts in East Africa, Hydrol. Earth Syst. Sci., 18, 611-620, https://doi.org/10.5194/hess-18611-2014, 2014.

Narasimhan, B. and Srinivasan, R.: Development and evaluation of Soil Moisture Deficit Index (SMDI) and Evapotranspiration Deficit Index (ETDI) for agricultural drought monitoring, Agr. Forest Meteorol., 133, 69-88, https://doi.org/10.1016/j.agrformet.2005.07.012, 2005.

Nelsen, R. B.: An Introduction to Copulas, 2nd Edn., SpringerVerlag, New York, https://doi.org/10.1007/0-387-28678-0, 2006.

NOAA: STAR-Global Vegetation Health Products. National Oceanic and Atmospheric Administration (NOAA), available at: https://www.star.nesdis.noaa.gov/smcd/emb/vci/VH/vh_ ftp.php (last access: 17 July 2019), 2011. 
NOAA: Climate Prediction Center's Hispaniola Hazards Outlook: October 5-October 11, 2017, Tech. rep., NOAA, 2017.

NOAA, USAID, and FEWSNET: Climate Prediction Center's Hispaniola Hazards Outlook For USAID/FEWS-NET, 1117 July 2013, Tech. rep., available at: https://origin.cpc.ncep. noaa.gov/products/international/camerica/camerica.shtml, (last access 15 July 2019), 2013.

OXFAM and Action contre la Faim: Etat des lieux de la situation de secheresse Dans les departements du Nord Ouest et du Haut Artibonite, Tech. rep., available at: https://reliefweb.int/sites/reliefweb.int/files/resources/ etatdeslieuxdelasituationdesecheresse.pdf (last access: 14 February 2020), 2015.

Palmer, W. C.: Keeping Track of Crop Moisture Conditions, Nationwide: The New Crop Moisture Index, Weatherwise, 21, 156-161, https://doi.org/10.1080/00431672.1968.9932814, 1968.

Peters, A. J., Walter-Shea, E. A., Ji, L., Vina, A., Hayes, M., and Svoboda, M. D.: Drought monitoring with NDVI-based Standardized Vegetation Index, Photogr. Eng. Remote S., 68, 71-75, 2002.

Sepulcre-Canto, G., Horion, S., Singleton, A., Carrao, H., and Vogt, J.: Development of a Combined Drought Indicator to detect agricultural drought in Europe, Nat. Hazards Earth Syst. Sci., 12, 3519-3531, https://doi.org/10.5194/nhess-12-3519-2012, 2012.

Serinaldi, F., Bonaccorso, B., Cancelliere, A., and Grimaldi, S.: Probabilistic characterization of drought properties through copulas, Phys. Chem. Earth, 34, 596-605, https://doi.org/10.1016/j.pce.2008.09.004, 2009.

Sheffield, J. and Wood, E. F.: Drought: Past Problems and Future Scenarios, Routledge, Earthscan, London, Washington, D.C., 2011.

Shiau, J.-T.: Fitting Drought Duration and Severity with TwoDimensional Copulas, Water Resour. Manage., 20, 795-815, https://doi.org/10.1007/s11269-005-9008-9, 2006.

Shiau, J.-T., Feng, S., and Nadarajah, S.: Assessment of hydrological droughts for the Yellow River, China, using copulas, Hydrol. Process., 21, 2157-2163, 2007.

Songbai, S. and Singh, V. P.: Frequency analysis of droughts using the Plackett copula and parameter estimation by genetic algorithm, Stoch. Env. Res. Risk A., 24, 783-805, 2010.

Svoboda, M., Lecomte, D., Hayes, M., Heim, R., Gleason, K., Angel, J., Rippey, B., Tinker, R., Palecki, M., Stooksbury, D., Miskus, D., and Stephens, S.: The drought monitor, B. Am. Meteorol. Soc., 83, 1181-1190, 2002.

Tadesse, T. and Wardlow, B. D.: The Vegetation Outlook (VegOut): A New Tool for Providing Outlooks of General Vegetation Conditions Using Data Mining Techniques, in: 7th IEEE International Conference on Data Mining Workshop, 28-31 October 2007, Omaha, NE, USA, 667-672, 2007.

Thornthwaite, C. W. and Mather, J. R.: The water balance, in: Publications in Climatology, Vol. 8, Drexel Institute of Technology, Laboratory of Climatology, Centerton, NJ, 1955.

Trading Economics: Haiti - Agricultural irrigated land (Percentage of total agricultural land), available at: https://tradingeconomics.com/haiti/agricultural-irrigated-landpercent-of-total-agricultural-land (last access: 21 August 2019), 2013.
USAID and FEWSNET: HAITI Food Security Outlook Update June 2012, Tech. Rep. April, available at: https://reliefweb.int/ report/haiti/haiti-food-security-outlook-update-june-2012 (last access: 21 August 2019), 2012a.

USAID and FEWSNET: HAITI: Food Security Outlook Update March 2012, Tech. Rep. February, FEWSNET, available at: http://fews.net/sites/default/files/documents/reports/Haiti_ FSOU_2012_03_En_Final.pdf (last access: 21 August 2019), 2012b.

USAID, MARNDR/CNSA, and FEWSNET: HAITI: Food Security Outlook Update June 2011, Tech. Rep. June, available at: https://reliefweb.int/report/haiti/ food-security-outlook-update-june-2011 (last access: $21 \mathrm{Au}$ gust 2019), 2011.

USDA Risk Management Agency, National Drought Mitigation Center, and University of Nebraska Lincoln: Weekly SPI, available at: http://greenleaf.unl.edu/ (last access: 21 August 2019), 2006.

Wang, L. and Qu, J. J.: NMDI: A normalized multi-band drought index for monitoring soil and vegetation moisture with satellite remote sensing, Geophys. Res. Lett., 34, 1-5, https://doi.org/10.1029/2007GL031021, 2007.

Wang, L., Li, X., Gong, J., and Song, C.: Vegetation temperature condition index and its application for drought monitoring, in: Geoscience and Remote Sensing Symposium, 9-13 July 2001, Sidney, Australia, 141-143, 2001.

Wilhite, D. A. (Ed.): Drought as a natural hazard: Concepts and definitions, in: Drought: A Global Assessment, Chap. 1, Routledge, London, 3-18, 2000.

World Bank: Haiti data, available at: https://data.worldbank.org/ country/haiti (last access: 25 August 2019), 2017.

World Meteorological Organization: Standardized Precipitation Index User Guide, Tech. Rep. 1090, World Meteorological Organization, Geneva, Switzerland, 2009.

World Meteorological Organization (WMO) and Global Water Partnership (GWP): Handbook of Drought Indicators and Indices, in: Integrated Drought Management Programme (IDMP), Integrated Drought Management Tools and Guidelines Series 2, edited by: Svoboda, M. and Fuchs, B. A., Geneva, ISBN 978-92-63-111739, 2016

Zargar, A., Sadiq, R., Naser, B., and Khan, F. I.: A review of drought indices, Environ. Rev., 19, 333-349, https://doi.org/10.1139/a11013, 2011.

Zhu, J., Pollanen, M., Abdella, K., and Cater, B.: Modeling Drought Option Contracts, ISRN Appl. Math., 2012, 1-16, https://doi.org/10.5402/2012/251835, 2012.

Zhu, Y., Wang, W., Singh, V. P., and Liu, Y.: Combined use of meteorological drought indices at multi-time scales for improving hydrological drought detection, Sci. Total Environ., 571, 10581068, https://doi.org/10.1016/j.scitotenv.2016.07.096, 2016. 